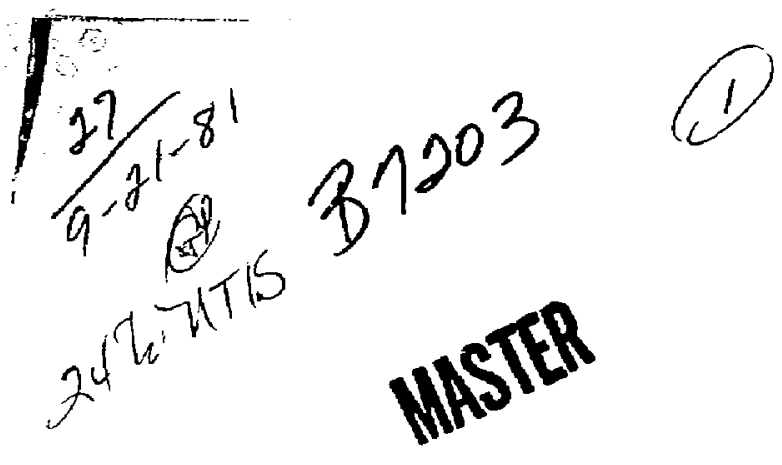

UCID- 19185

\title{
A SUMMARY OF
}

THE LLNL ONE-DIMENS IONAL TRANSPORT-KINETICS MODEL OF THE TROPOSPHERE AND STRATOSPHERE: 1981

D. J. Wuebbles

Septemter, 1981

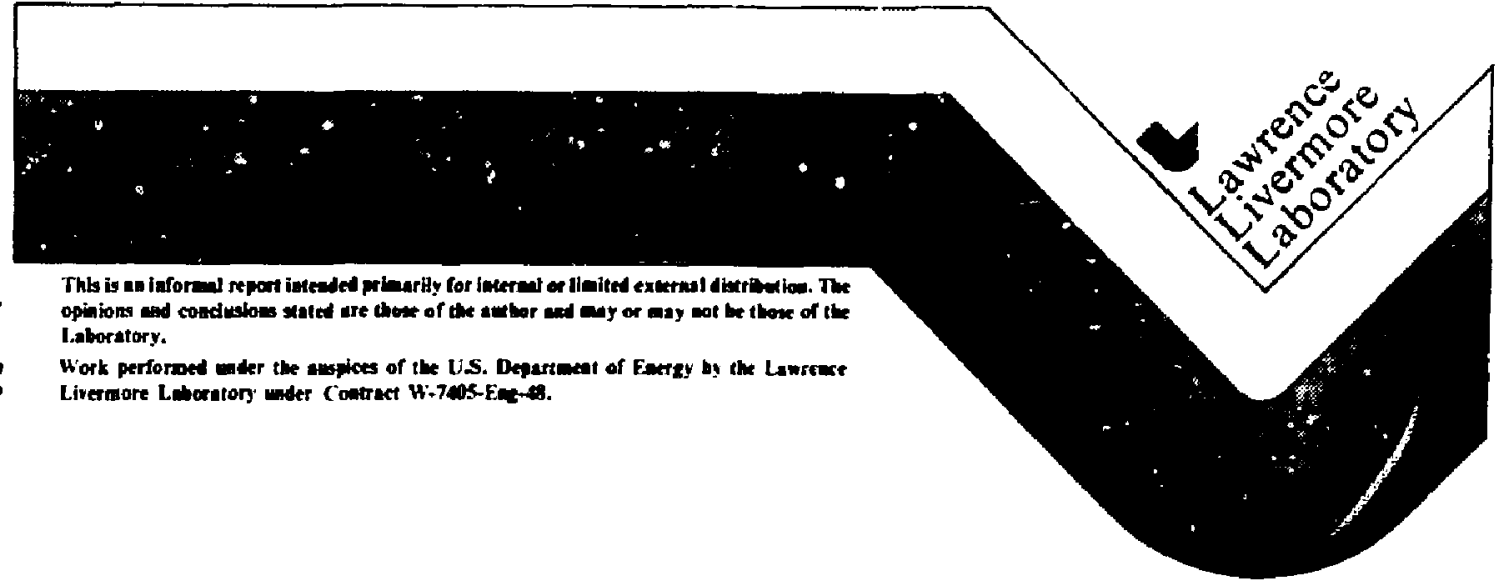




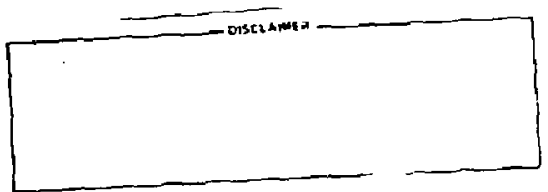

ISLUMRY OF

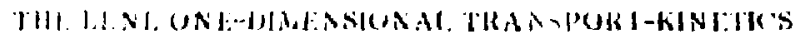

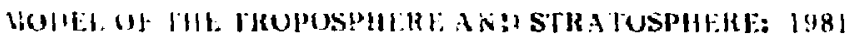

$$
\text { 1). .. Wue!sbles }
$$

Septemher, 1981

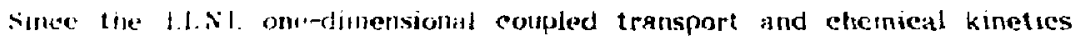
uodei of the troposphme anr' stratosphere was originany developed in 1972 (6hang el al., 1974), there have been many changes to the inodel's representation of

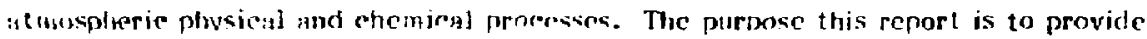
:a briet description of the aurrent I.I.NI. onedimensional coupled transport and

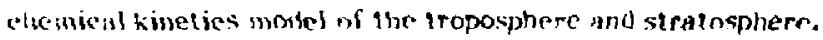

\section{Siojel Structure:}

The LANL 1-13 model eurrenty oxtends from the ground to $56.25 \mathrm{fm}$. The vertical griu structure is variable, but usually has a $0.5-k$ inthich layes at the surtace. I-kin thikh byyers exlenuing trom 0.5 to $34.5 \mathrm{~km}$. a $1.75 \mathrm{~km}$ thiek layer yetween 34.5 and $31.2 .25 \mathrm{~km}$ and $2.5 \mathrm{~km}$ thick lavers extending to $56.25 \mathrm{~km}$.

Work performed under the auspices of the U.S. Uepartment of Energy by the lavirence livermore National Laboratory under contract $\mathbf{W}-\mathbf{7 4 0 5}-\mathbf{E} \mathrm{g}-48$. 
Three of the minor constituents, $O\left({ }^{1} \mathrm{D}\right), \mathrm{H}$, and $N$ in the model are assumed to be in instantaneous equilibrium. EHch of the other $\mathbf{4 4}$ species in the model has its concentation calculated at each of 44 vertichl levels extending from the surface to $56.25 \mathrm{~km}$. There is a continuty equation describing the sime rate of change of oach of the 44 minor constituents at euch altitude. The numerical technique used to solve the set of approximately 2010 differential equations (resulting from $n$ continuity equation for eneh species at each grid tevel) is the (iliak methou as described by (llangs et al. (1974). The main advuntape of this method, whieh is variable oreler, multistop, implicit method, is its ability to solve sc:- of

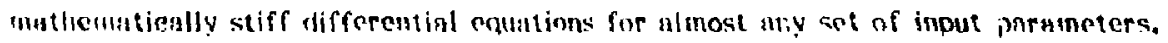
intial and boundary roflditions, in marticular those resulting from the ehemical kinetiess system.

\section{TRANSPORT PARAUITRRIZATION}

The transport of atmospheric trace constituents in the 1-D medel, is an cimpirical representition not utilizing observed atmospheric motion directly but rather is based on the otservations of the temporal and spatial distributions of selected trace species. In the LLNL onc-dimensional model, the $k_{z}$ profile was origmally based on in amblysts of $\mathrm{CH}_{1}$ and $\mathrm{N}_{2} \mathrm{O}$ merstrements (chang in $\mathrm{NRC}$, lyz (i) with consideration also given to mrusurements of radjonuelide debris transport in the lower stratosphere. This $h_{z}$ profile is shown in Figure 1. Although this $k_{z}$ profile is usea in nost model talculations, other $k_{2}$ representations, such as those used in other models muy toe usect as well. Several $k_{z}$ profiles have been used to test the sensitivity of caleunted results to transport parameterization uncertuinties (Clanor, l974; Luewer et al., I977; Luther et al., 1979). 


\section{Chemical Kinetics System}

The LLNL 1-D model presently contains 141 chemical and photochemical reactions to deternine the concentrations of 47 minor atmospheric constituents. These constituents include all of the known odd oxygen $\left(O_{x}\right)$, odd hydrogen ( $\left.1 O_{x}\right)$, odd ehlorine (ClO) $)_{4}$ and and nitrogen (NO $)^{\prime}$ species important 10 tropospheric and stratospheric chemistry. Also included are souree species $\left(\mathrm{N}_{2} \mathrm{O}\right.$, 11,2 , chlorocarbons), plus all of the speeis resulting from methane oxidation.

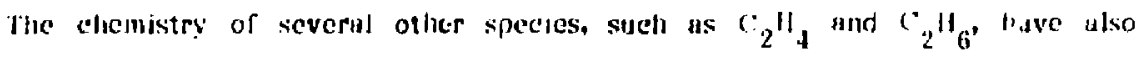
been studied with tl:o model, but u'w 1 ot included here. Sulfur chemistry will be Hatled to the model in the near fut ure fol stulying the sirncospherie gerosol hyver.

The chemistry used eurrently in the model is primarily that recommended by the joint meeting of the NASA Panel for bata livaluation and the colvatet Tank Liroup on rhemical kinetics in March, 1981 (W. Vemore, privale communication, 1 y811. Iubles 1 throug:l 3 show the reastions and rates eurrently in the model. For the photorissociation reactions (Tanle 3), the sources of the absorption eross-sections and quantun yields used in the model to compute photodissoeiation pates are slown. Several reactions are included that are not given in the NASA-COJAAI recommenciations. These reactions mostly invoive chlorocarbons whose rates have been mensured (but not consivered in the NASA-COIDATA lecommendition) or for which reasomable estimates of the reaction rute cun be made. There are also several reactions inclinded for which rate estimates are made based on sitilatar corresponding reactions.

The model is programmed such that any chemical rate can easily be modified. This ability is extremely useful in testing the effect of new laboratory ineasurements or studying the effeet of reaction rate uncertainties. For example, the previous NASA Panel recommendations (NASA Panel for Data Evaluation, 1981) 
gave two possible rates for CRONO, (enlorine nitrate) production. The faster of these rates is based on the rate of $\mathrm{ClO}+\mathrm{NO}_{2}$ in laboratory studies, while the slower rate reflects the possibility, also based on laboratory studies, that chlorine nitrate isomers are being formed us well as $\mathrm{CLONO}_{2}$, These isomers are assumed to dissaciate immediately. In the model, the slower rate is used, as recommended by the combined NASs-CUDA'tA Pancts, However, it is straightforward in test the sensitivity of the monel to the faster rnte as well. 
TABLE 1. Chemical reactions and rate coefficients where $k=A e^{B / T}$ used in the 1981 model ehemistry.

\begin{tabular}{|c|c|c|c|c|}
\hline & IResction & $A$ & F. & Note \\
\hline 1. & $O+O_{2}+M+O_{3}+N$ & see Table 2 & & 3 \\
\hline 2. & $0+o_{3}+20_{2}$ & $1.5 \times 10^{-11}$ & -2218 & 1 \\
\hline 3. & $\mathrm{O}_{3}+\mathrm{NO}+\mathrm{NO}_{2}+\mathrm{C}_{2}$ & $3.8 \times 10^{-12}$ & -1580 & I \\
\hline 4. & $\mathrm{O}+\mathrm{NO}_{2}+\mathrm{NO}^{2}+\mathrm{O}_{2}$ & $9.3 \times 10^{-12}$ & a & 1 \\
\hline 5. & $N_{2} \mathrm{O}+\mathrm{O}\left({ }^{2} \mathrm{D}\right)+\mathrm{N}_{2}+\mathrm{U}_{2}$ & $4.4 \times 10^{-12}$ & (1) & 1 \\
\hline b. & $\left.\mathrm{N}_{2}^{2} \mathrm{U}+\mathrm{O}^{(3} \mathrm{U}\right)+2 \mathrm{NO}$ & $7.2 \times 10^{-11}$ & u & 1 \\
\hline 7. & $\mathrm{~N}+\mathrm{O}_{2}+\mathrm{Nu}+\mathrm{O}$ & $4.4 \times 10^{-12}$ & $-3 \bar{z} \bar{a} 0$ & 1 \\
\hline 8. & $N+N U+N_{2}+U$ & $3.4 \times 10^{-12}$ & 0 & 1 \\
\hline 9. & $O\left({ }^{3} D\right)+H_{2} O+2 O H$ & $2.3 \times 10^{-10}$ & o & 1 \\
\hline 10. & $\mathrm{O}_{3}+\mathrm{OH} \rightarrow \mathrm{HO}_{2}+\mathrm{O}_{2}$ & $1.6 \times 10^{-12}$ & -940 & 1 \\
\hline 11. & $\mathrm{U}+\mathrm{OH}+\mathrm{O}_{2}+\mathrm{H}$ & $2.3 \times 10^{-21}$ & +110 & 1 \\
\hline 12. & $\mathrm{O}_{3}+11 \mathrm{O}_{2}+0 \mathrm{OH}+2 \mathrm{O}_{2}$ & $1.4 \times 10^{-14}$ & -580 & $!$ \\
\hline 13. & $\mathrm{O}+11 \mathrm{u}_{2}+\mathrm{OH}+\mathrm{O}_{2}$ & $3.5 \times 10^{-11}$ & a & 1 \\
\hline 14. & $\mathrm{H}+\mathrm{O}_{2}+\mathrm{M} \rightarrow \mathrm{HO} \mathrm{O}_{2}+\mathrm{M}$ & see Table 2 & & 3 \\
\hline 15. & $\mathrm{o}_{3}+11+\mathrm{OH}_{2}+\mathrm{v}_{2}$ & $1.4 \times 10^{-10}$ & $-4 / 0$ & 1 \\
\hline 16. & $\mathrm{HO}_{2}+\mathrm{HO}_{2}+\mathrm{H}_{2} \mathrm{O}_{2}+\mathrm{O}_{2}$ & $3.0 \times 10^{-12}$ & $\mathbf{0}$ & 1 \\
\hline 17. & $\mathrm{HO}_{2}+\mathrm{OH}+\mathrm{H}_{2} \mathrm{O}+\mathrm{O}_{2}$ & $8.0 \times 10^{-11}$ & 0 & 1 \\
\hline 18. & $\mathrm{OH}+\mathrm{NO}_{2}+\mathrm{M}+\mathrm{HNO}_{3}+\mathrm{M}$ & see Table 2 & 1 & \\
\hline 19 & $\mathrm{OH}+\mathrm{HNO}_{3}+\mathrm{H}_{2} \mathrm{O}+\mathrm{NO}_{3}$ & $1.52 \times 10^{-13}$ & +649 & 1,10 \\
\hline 20. & $\mathrm{H}_{2} \mathrm{O}_{2}+\mathrm{OH}+\mathrm{H}_{2} \mathrm{O}+\mathrm{HO}_{2}$ & $2.9 \times 10^{-12}$ & -160 & 1 \\
\hline 21. & $N_{2}+O(1 D)+M \rightarrow N_{2} O+N$ & see Troble 2 & & 3 \\
\hline 22. & $\mathrm{~N}+\mathrm{NO}_{2}+\mathrm{N}_{2} \mathrm{O}+\mathrm{O}$ & $2.1 \times 10^{-11}$ & -800 & 2 \\
\hline 23. & $\mathrm{NO}+\mathrm{O}+\mathrm{M} \rightarrow \mathrm{NO}_{2}+\mathrm{M}$ & see Trble 2 & & 3 \\
\hline 24. & $\mathrm{NO}+\mathrm{HO}_{2}+\mathrm{NO}_{2}+\mathrm{OH}$ & $3.7 \times 10^{-12}$ & +240 & 1 \\
\hline 25. & $H_{2}+O\left({ }^{2} v\right)+O H+H$ & $1.1 \times 10^{-10}$ & 0 & 1 \\
\hline 26. & $\mathrm{OH}+\mathrm{OH}+\mathrm{H}_{2} \mathrm{O}+\mathrm{O}$ & $4.5 \times 10^{-12}$ & -275 & 1 \\
\hline 27. & $\mathrm{~N}+\mathrm{O}_{3} \rightarrow \mathrm{NO}+\mathrm{O}_{2}$ & $2.0 \times 10^{-13}$ & -3000 & 4 \\
\hline 28. & $\mathrm{NO}_{2}+\mathrm{O}_{3}+\mathrm{NO}_{3}+\mathrm{O}_{2}$ & $1.2 \times 10^{-13}$ & -2450 & 1. \\
\hline
\end{tabular}


TABI,E 1. Continued

\begin{tabular}{|c|c|c|c|c|}
\hline & Reaction & $\Lambda$ & B & Note \\
\hline 29. & $\mathrm{OH}+\mathrm{OH}+\mathrm{H}+\mathrm{H}_{2} \mathrm{O}_{2}+\mathrm{M}$ & see Table 2 & & 3 \\
\hline 30. & $\mathrm{H}_{2} \mathrm{O}_{2}+\mathrm{O} \rightarrow \mathrm{OH}+\mathrm{HO}_{2}$ & $1.0 \times 10^{-11}$ & -2500 & $\mathbf{1}$ \\
\hline 31. & $\mathrm{CO}+\mathrm{OH}+\mathrm{H}+\mathrm{H}+\mathrm{CO}_{2}+\mathrm{H}$ & see Table 2 & & 3 \\
\hline 32. & $O\left({ }^{1} D\right)+M+O+M$ & $2.1 \times 10^{-11}$ & 99 & 5 \\
\hline 33. & $\mathrm{Cl}+\mathrm{O}_{3}+\mathrm{ClO}_{2}+\mathrm{O}_{2}$ & $2.8 \times 10^{-11}$ & -257 & $!$ \\
\hline 34. & $\mathrm{Cl}+\mathrm{NO}_{2}+\mathrm{M}+\mathrm{Cl} \mathrm{NO}_{2}+\mathrm{M}$ & sec Thole 2 & & 3 \\
\hline 35. & $120+0+12+0)_{2}$ & $7.7 \times 10^{-11}$ & -130 & 1 \\
\hline 36. & $\mathrm{NO}+\mathrm{ClO}+\mathrm{NO}_{2}+\mathrm{Cll}$ & $\left(6.2 \times 10^{-12}\right.$ & 294 & 1 \\
\hline 37. & $(2)+\mathrm{NO}_{2}+\mathrm{H}+1 \cdot 20 \mathrm{NO}_{2}+\mathrm{H}$ & sce Joble 2 & & 3 \\
\hline 38. & $H C l+O\left({ }^{1}(1)+C l+O H\right.$ & $1.4 \times 10^{-10}$ & 0 & 1 \\
\hline 39. & $\mathrm{OH}+\mathrm{HCl}=\mathrm{HI}_{2} \mathrm{O}+\mathrm{Cl}$ & $2.8 \times 10^{-12}$ & -425 & 1 \\
\hline 40. & $\mathrm{O}+111 \mathrm{C} \ell+0 \mathrm{OH}+\mathrm{C} Q$ & $1.14 \times 10^{-11}$ & -3370 & 1 \\
\hline+1 & $\mathrm{Cl}+\mathrm{HO}_{2}+\mathrm{HCl}+\mathrm{O}_{2}$ & $4.8 \times 10^{-11}$ & 0 & 1 \\
\hline 42. & $\mathrm{CFCl}_{3}+\mathrm{O}^{(1}(1)+3 \mathrm{Cl}^{2}$ & $2.2 \times 10^{-10}$ & 0 & 1,6 \\
\hline 43. & $\left.C F_{2} r l_{2}^{B}+\left({ }^{1}{ }^{1} D\right)\right)+2 C l$ & $1.4 \times 10^{-10}$ & 0 & 1,6 \\
\hline 44. & $\mathrm{Cl}^{2}+\mathrm{H}_{2}^{2}+\mathrm{HCl}+\mathrm{H}^{2}$ & $3.5 \times 10^{-11}$ & -2290 & I \\
\hline 45. & $\mathrm{CO}^{\mathrm{C}}+\mathrm{H}_{2} \mathrm{O}_{2}+\mathrm{Hr} \mathrm{C}+11 \mathrm{O}_{2}$ & $1.1 \times 10^{-11}$ & -980 & 1 \\
\hline 46. & $1 \cdot 2 \mathrm{NNO}_{2}+\mathrm{U}+\mathrm{r} \cdot \mathrm{lu}+\mathrm{NO}_{3}$ & $3.0 \times \mathrm{i}^{-12}$ & -8118 & 1,10 \\
\hline 47. & $\mathrm{CH}_{3} \mathrm{Cl}+\mathrm{CHH}+\mathrm{Cl}+\mathrm{H}_{2} \mathrm{O}+\mathrm{HO}_{2}$ & $1.8 \times 10^{-12}$ & -1112 & 1,6 \\
\hline 48. & $\mathrm{NO}+\mathrm{NO}_{3}+2 \mathrm{NO}_{2}$ & $2.0 \times 10^{-11}$ & $\mathbf{0}$ & 1 \\
\hline 49. & $\mathrm{NO}_{2}+\mathrm{O}+\mathrm{N}+\mathrm{NO}_{3}+W$ & see Table 2 & & 3 \\
\hline 50. & $\mathrm{NO}_{2}+\mathrm{NO}_{3}+\mathrm{H}+\mathrm{N}_{2} \mathrm{O}_{3}+\mathrm{H}_{1}$ & see Table 2 & & 3 \\
\hline 51. & $\mathrm{~N}_{2} \mathrm{CH}_{5}+\mathrm{H}+\mathrm{NO}_{2}+\mathrm{NO}_{3}+\mathrm{H}$ & see Table 2 & & 3 \\
\hline .72. & $\mathrm{~N}_{2} \mathrm{U}_{5}+\mathrm{II}_{2} \mathrm{U}+2 \mathrm{HNO}_{3}$ & $5.0 \times 10^{-22}$ & 0 & 7 \\
\hline 53. & $u^{2}(D)+u_{3}+2 O_{2}$ & $1.2 \times 10^{-10}$ & 0 & 1 \\
\hline 54. & $\mathrm{HO}_{2}+\mathrm{HO}_{2}+\mathrm{H}_{2} \mathrm{U} \rightarrow \mathrm{H}_{2} \mathrm{O}_{2}+\mathrm{O}_{2}+\mathrm{H}_{2} \mathrm{O}$ & sec Thble 2 & & 3 \\
\hline 5.5 & $\mathrm{O}+\mathrm{NO}_{3} \rightarrow \mathrm{O}_{2}+\mathrm{NO}_{2}$ & $1.0 \times 10^{-11}$ & $\mathbf{0}$ & 1 \\
\hline 56. & $\mathrm{HO}_{2}+\mathrm{NO}_{2}+\mathrm{MI}+\mathrm{HNO}_{4}+\mathrm{Ml}$ & see Table 2 & & 3 \\
\hline 57. & $\mathrm{HNO}_{4}+\mathrm{MH}^{2} \mathrm{HO}_{2}+\mathrm{NO}_{2}+\mathrm{M}$ & see Table 2 & & 3 \\
\hline 58. & $\mathrm{OH}+\mathrm{HNO}_{4} \rightarrow \mathrm{II}_{2} \mathrm{O}+\mathrm{NO}_{2}+\mathrm{O}_{2}$ & $4.0 \times 10^{-12}$ & 0 & 1,10 \\
\hline 59. & $\mathrm{Cl}+\mathrm{HNO}_{4}+\mathrm{HCl}+\mathrm{NO}_{2}+\mathrm{O}_{2}$ & $3.0 \times 10^{-12}$ & -300 & 8 \\
\hline 60. & $\mathrm{HO}_{2}+\mathrm{ClO}+\mathrm{O}_{2}+\mathrm{HOCl}$ & $4.6 \times 10^{-13}$ & 710 & I \\
\hline 61. & $\mathrm{Cl}+\mathrm{HOCl}+\mathrm{HCl}+\mathrm{ClO}$ & $3.0 \times 10^{-12}$ & -300 & 8 \\
\hline
\end{tabular}


TABLE 1. Continued

\begin{tabular}{|c|c|c|c|c|}
\hline & Reaction & $A$ & $\mathbf{B}$ & Note \\
\hline 62. & $\mathrm{OH}+\mathrm{HOCl}+\mathrm{H}_{2} \mathrm{O}+\mathrm{ClO}$ & $3.0 \times 10^{-12}$ & -150 & 1 \\
\hline 63. & $\mathrm{O}+\mathrm{HOCl}+\mathrm{OH}+\mathrm{ClO}$ & $1.0 \times 10^{-11}$ & -2200 & 1 \\
\hline 64. & $\mathrm{OH}+\mathrm{CH}_{4}+\mathrm{Cll}_{3}+\mathrm{HI}_{2} \mathrm{O}$ & $2.4 \times 10^{-12}$ & -1710 & 1 \\
\hline 65. & $\mathrm{O}+\mathrm{CH}_{4}^{4}+\mathrm{CH}_{3}+\mathrm{OH}^{2}$ & $3.5 \times 10^{-11}$ & -4550 & 1 \\
\hline fit. & $\mathrm{O}\left({ }^{\prime} \mathrm{L}\right)+\mathrm{CH}_{4}+\mathrm{CH}_{2} \mathrm{O}+\mathrm{H}_{2}$ & $1.5 \times 10^{-11}$ & $\mathbf{0}$ & $\mathbf{I}$ \\
\hline 67. & $\mathrm{O}\left({ }^{1} \mathrm{n}\right)+\mathrm{CH}_{4}^{4}-\mathrm{CH}_{3}^{2}+\mathrm{OH}^{2}$ & $1.4 \times 10^{-10}$ & 0 & 1 \\
\hline fis. & $\mathrm{CH}_{4}+\mathrm{Cl}+\mathrm{HCl}_{2}+\mathrm{CH}_{3}$ & $9.6 \times 19^{-12}$ & -1350 & 1 \\
\hline 6is. & $\mathrm{Cl}+\mathrm{CH}_{3} \mathrm{Cl}+\mathrm{HO}_{2}+\mathrm{CO}+2 \mathrm{HCl}$ & $3.4 \times 10^{-11}$ & -1260 & 1,6 \\
\hline 70. & $\mathrm{Cli}_{3} \mathrm{O}_{2}+\mathrm{NO}+\mathrm{NO}_{2}^{2}+\mathrm{CH}_{3} \mathrm{O}$ & $7.4 \times 10^{-12}$ & $\mathbf{0}$ & 1 \\
\hline 71 & $\mathrm{Cl}+\mathrm{CH}_{2} \mathrm{O}+\mathrm{HCCl}+\mathrm{HCO}$ & $8.2 \times 10^{-11}$ & -34 & $!$ \\
\hline 72. & $\mathrm{CH}_{3} \mathrm{O}_{2}+\mathrm{HO}_{2}+\mathrm{CH}_{3} \mathrm{OOH}+\mathrm{O}_{2}$ & $6.0 \times 10^{-14}$ & o & 1 \\
\hline 73. & $\mathrm{CH}_{3} \mathrm{O}+\mathrm{O}_{2}+\mathrm{CH}_{2} \mathrm{O}+\mathrm{HO}_{2}$ & $1.0 \times 10^{-12}$ & -2050 & 1 \\
\hline 74. & $\mathrm{OH}+\mathrm{CH}_{2} \mathrm{O}+\mathrm{H}_{2} \mathrm{O}+\mathrm{HCO}^{2}$ & $1.0 \times 10^{-11}$ & 0 & 1 \\
\hline 75. & $\mathrm{O}+\mathrm{CH}_{2} \mathrm{O}+1 \mathrm{iCO}+\mathrm{OH}$ & $3.0 \times 10^{-11}$ & -1550 & 1,10 \\
\hline 76. & $\mathrm{HCO}+\mathrm{O}_{2}+\mathrm{CO}+\mathrm{HO}_{2}$ & $5.0 \times 10^{-12}$ & 0 & 1 \\
\hline $7 \%$ & $\mathrm{OH}+\mathrm{CH}_{3} \mathrm{OOH} \rightarrow \mathrm{CH}_{3} \mathrm{O}_{2}+\mathrm{H}_{2} \mathrm{O}$ & $2.2 \times 10^{-12}$ & -160 & 1,10 \\
\hline 78. & $\mathrm{CH}_{3}+\mathrm{O} \rightarrow \mathrm{CH}_{2} \mathrm{O}+\mathrm{H}$ & $1.3 \times 10^{-10}$ & 0 & 1 \\
\hline $7 y$. & $\mathrm{CH}_{3} \mathrm{O}_{2}+\mathrm{O}_{3}+\mathrm{CH}_{3} \mathrm{O}+2 \mathrm{O}_{2}$ & $1.0 \times 10^{-14}$ & -600 & 9 \\
\hline 80. & $\mathrm{CH}_{3} \mathrm{O}_{2}+\mathrm{O} \rightarrow \mathrm{CH}_{3} \mathrm{O}+\mathrm{O}_{2}$ & $3.0 \times 10^{-11}$ & $\mathbf{0}$ & 9 \\
\hline 81. & $\mathrm{ClO}+\mathrm{OH}+\mathrm{HO}_{2}+\mathrm{Cl}$ & $9.1 \times 10^{-12}$ & 0 & 1,10 \\
\hline 82. & $\mathrm{CH}_{3}+\mathrm{O}_{2}+\mathrm{H}+\mathrm{CH}_{3} \mathrm{O}_{2}+\mathrm{M}$ & see Table 2 & & 3 \\
\hline 83. & $\mathrm{C} 2 \mathrm{O}+\mathrm{OH}+I I C R+\mathrm{O}_{2}$ & Not used $\left(210^{-22}\right)$ & & \\
\hline 84. & $\mathrm{H}_{2}+\mathrm{OH}+\mathrm{H}_{2} \mathrm{O}+\mathrm{H}^{2}$ & $7.7 \times 10^{-12}$ & -2100 & l \\
\hline 85. & $\mathrm{H}+\mathrm{H}_{2} \rightarrow \mathrm{H}_{2}+\mathrm{O}_{2}$ & $4.2 \times 10^{-11}$ & -350 & 12 \\
\hline 86. & $\mathrm{OH}+\mathrm{CH}_{3} \mathrm{OOH}+\mathrm{CH}_{2} \mathrm{O}+\mathrm{H}_{2} \mathrm{O}+\mathrm{CH}$ & $5.0 \times 10^{-12}$ & -750 & 1,10 \\
\hline 87. & $\mathrm{O}+\mathrm{HNO}_{4}+\mathrm{UH}+\mathrm{NO}_{2}+\mathrm{O}_{2}$ & $7.4 \times 10^{-12}$ & -2630 & 1,10 \\
\hline 88. & $\mathrm{OH}+\mathrm{ClONO}_{2}+\mathrm{HOCl}+\mathrm{NO}_{3}$ & $1.2 \times 10^{-12}$ & -333 & 1,10 \\
\hline 89. & $\mathrm{Cl}+\mathrm{ClONO}+2 \mathrm{Cl}+\mathrm{NO}_{3}$ & $1.7 \times 10^{-12}$ & -607 & 1,10 \\
\hline 90. & $\mathrm{HONO}+\mathrm{OH}^{2} \rightarrow \mathrm{H}_{2} \mathrm{O}+\mathrm{NO}_{2}$ & $6.6 \times 10^{-12}$ & 0 & 12 \\
\hline 91. & $\mathrm{OH}+\mathrm{NO}+\mathrm{H}+\mathrm{HONO}+\mathrm{HI}$ & see Table 2 & & 3 \\
\hline 92. & $\mathrm{O}+\mathrm{OClO} \rightarrow \mathrm{C} 2 \mathrm{O}+\mathrm{O}_{2}$ & $2.5 \times 10^{-11}$ & -1166 & 1 \\
\hline 93. & $\mathrm{NO}+\mathrm{OCLO} \rightarrow \mathrm{NO}_{2}+\mathrm{ClO}$ & $2.5 \times 10^{-12}$ & -600 & 1 \\
\hline
\end{tabular}


TARI,I: 1. Continued

\begin{tabular}{|c|c|c|c|c|}
\hline & Reaetion & A & B & Note \\
\hline 94. & $\mathrm{OH}+\mathrm{CH}_{3} \mathrm{YCl} \mathrm{Cl}_{3}+\mathrm{H}_{2} \mathrm{O}+3 \mathrm{Cl}$ & $5.4 \times 10^{-12}$ & -1820 & 1,6 \\
\hline E5. & $\mathrm{UH}_{t}+\mathrm{CHC}-21+2 \mathrm{Cl}$ & $8.9 \times 10^{-13}$ & -1013 & 1,6 \\
\hline 96. & $a(+1)+C l(c-13+c e$ & $1.0 \times 10^{-10}$ & 0 & 11 \\
\hline 97. & $\left(x^{+}(1)\right)+(2)(;-1)+4 c 2$ & $3.0 \times 10^{-10}$ & $\theta$ & $t 1$ \\
\hline 98. & $O H+C F C-142 i)+C l$ & $1.5 \times 10^{-12}$ & -1800 & 12 \\
\hline 94. & $u(d))+(21)(-113+3 x)$ & $2.75 \times 10^{-10}$ & 0 & 13 \\
\hline IIII. & $O(1))+C(:(:-1) 4+2 C: Q$ & $1.62 \times 10^{-10}$ & ) & 13 \\
\hline IIII. & $O(1))+(2)\left(-115+c^{\prime} l\right.$ & $1.00 \times 10^{-10}$ & 0 & 14 \\
\hline 102. & $\mathrm{OH}+\mathrm{CFC}-22 \rightarrow \mathrm{H}_{2} \mathrm{O}+\mathrm{Cl}$ & $2.8 \times 10^{-13}$ & -1530 & 1,6 \\
\hline 103. & $\left.U\left(l^{1} 1\right)\right)+\left(r \cdot l^{4}+4 x^{2} l\right.$ & $3.5 \times 10^{-10}$ & 0 & 1,6 \\
\hline
\end{tabular}


NOTES TO TABLF. I

'Draft report of the joint meeting of the NASA Panel for Data Fral:mtion and the CODATA Task Jroup on Chemical Kinetics (h. Deliure, private corninunication, 1981 \}.

2. NASA Panel tor Data Evaluation (JPL, 8I-3), 1981.

3. The reaction is prossure dependent. Soc Table A-2 for diseussion.

4. Listimate Jesigned to be compatib]e with upper limit given in referenee 1 , and low enough to have no signifiennt effeet on model performance. Renetion is retained only to facilitate reintroduction if the evuluated upper limit should prove to be in error.

5. Heighted average of the rates of $u\left({ }^{1}(\nu)+N_{2}\right.$ and $u\left(\left(^{1} L\right)+U_{2}\right.$ from reference 1.

f. Product chemistry has been simplifiet.

7. Fstimated regetion rate, This estimate is designed to inelude a possible heterogencous contribution to the overall reaction. Important only in the lower troposphere.

8. Estimated reaction rate. This rate is estimated based on the assumption that $\mathrm{H}_{\mathrm{NO}_{4}}$ and HOCl resemble $\mathrm{H}_{2} \mathrm{O}_{2}$ (as treated in JPL, 1979) in reactions with $\mathrm{Cl}$ and $\mathrm{OH}$.

9. Fstimated reaction rate. Rate is estimated hased on the assumption that $\mathrm{rH}_{3} \mathrm{O}_{2}$ elosely resenbles $\mathrm{HU}_{2}$ in react ion with $\mathrm{O} \mathrm{Or}_{3}$.

10. Products are not given in references 1 or 2. The assumed products are based on products that seem the most chemically plausible.

11. Based on formula given in Lavidson et al., (1978).

12. Llampson (1980).

13. Pits et ul. (1974).

14. Listimate besed on consideration of reaction rate of other molecules with $\mathrm{O}^{(\mathrm{L} D)}$.

15. $\mathrm{CEC-21}=\mathrm{CHFC \ell _{2 }}$

$\mathrm{CEC}-22=\mathrm{CH} \mathrm{F} \mathrm{Cl}_{2}$

$\mathrm{CFC}-13=\mathrm{CCl} \mathrm{F}_{3}$

$\mathrm{CHC}_{\mathrm{C}} 12=\mathrm{CFCl}_{2} \mathrm{CF} \mathrm{Cl} 2$

$\mathrm{CFC}-142 \mathrm{~b}=\mathrm{CH}_{3} \mathrm{C} \mathrm{ClF} 2$

$\mathrm{CEC}-1 \mathrm{I3}=\mathrm{CFCl}_{2} \mathrm{CF}_{2} \mathrm{Cl}$

$\mathrm{CFC}-114=\mathrm{CF}_{2} \mathrm{Cl} \mathrm{CF}_{2} \mathrm{Cl}$

$\mathrm{CFC}-115=\mathrm{CF}_{2} \mathrm{Cl} \mathrm{CF}_{3}$ 
TARLE 2. Rate enof !eicuts used for pressure-dependent reactions.

Expression l:

$$
\left.k=\frac{A_{0}[W](300 / T)^{n_{0}}}{1+A_{0}[M](300 / T)^{n} / A_{i}(300 / T)^{1 T_{i}}} 0.6^{1 / D}, D=1+\log _{10} \frac{A_{0}[H](300 / T)^{n_{0}}}{A_{i}(300 / T)^{n_{i}}}\right\}_{2}
$$

\begin{tabular}{|c|c|c|c|c|c|}
\hline Reaction & Ao & $n_{0}$ & $\dot{A}_{\mathbf{i}}$ & $n_{i}$ & Note \\
\hline \multirow{5}{*}{$\begin{array}{l}\mathrm{HO}_{2}+\mathrm{NO}_{2}+\mathrm{M}+\mathrm{HNO}_{4}+\mathrm{N} \\
\mathrm{OH}+\mathrm{NO}_{2}+\mathrm{H}+\mathrm{HNO}_{3}+\mathrm{M} \\
\mathrm{ClO}+\mathrm{NO}_{2}+\mathrm{M}+\mathrm{ClONO}_{2}+\mathrm{H} \\
\mathrm{O}+\mathrm{O}_{2}+\mathrm{M}+\mathrm{O}_{3}+\mathrm{N}\end{array}$} & $2.1 \times 10^{-31}$ & $\mathbf{5}, 0$ & $6.5 \times 10^{-12}$ & $\mathbf{2 . 0}$ & 1 \\
\hline & $2.5 \times 10^{-30}$ & 2.0 & $2.4 \times 10^{-11}$ & $1+3$ & 1 \\
\hline & $4.5 \times 10^{-32}$ & 3.8 & $1.5 \times 10^{-12}$ & 1.4 & 1,2 \\
\hline & $1.6 \times 10^{-31}$ & 3.4 & $1.5 \times 10^{-11}$ & 1.9 & 1,2 \\
\hline & $6.2 \times 10^{-34}$ & 2.1 & -- & - & 1 \\
\hline $\mathrm{CH} \mathrm{H}_{3}+\mathrm{O}_{2}+\mathrm{MI}+\mathrm{CH}_{3} \mathrm{O}_{2}+\mathrm{M}$ & $2.2 \times 10^{-312}$ & $2+2$ & $2.0 \times 10^{-12}$ & 1.7 & 1 \\
\hline $\mathrm{O}(\mathrm{D})+\mathrm{N}_{2}+\mathrm{H}+\mathrm{N}_{2} \mathrm{O}+\mathrm{N}$ & $3.5 \times 10^{-31}$ & 0.45 & -- & -- & 1 \\
\hline $\mathrm{Cl}+\mathrm{NO}_{2}+\mathrm{M}+\mathrm{ClNO}$ & $1.6 \times 10^{-30}$ & 1.9 & $3.0 \times 10^{-11}$ & 1.0 & 1 \\
\hline $\mathrm{H}+\mathrm{O}_{2}+\mathrm{M}+\mathrm{HO}_{2}+\mathrm{M}$ & $5.5 \times 10^{-32}$ & 1.4 & -- & - & 1 \\
\hline $\mathrm{OH}+\mathrm{NO}+\mathrm{M} \rightarrow \mathrm{HNO}_{2}+\mathrm{M}$ & $6.7 \times 10^{-33}$ & 3,3 & $3.0 \times 10^{-11}$ & 1.0 & 1 \\
\hline $\mathrm{HH}+\mathrm{OH}+\mathrm{H}+\mathrm{H}_{2} \mathrm{O}_{2}+\mathrm{M}$ & $2.5 \times 10^{-31}$ & 0.6 & $3.0 \times 10^{-11}$ & I. 11 & 1 \\
\hline $\mathrm{NO}_{2}+\mathrm{NO}_{3}+\mathrm{M}+\mathrm{N}_{2} \mathrm{O}_{5}+\mathrm{Al}$ & $1.4 \times 10^{-30}$ & 2,8 & $8.0 \times 10^{-13}$ & 0 & 1 \\
\hline $\mathrm{O}+\mathrm{NO}+\mathrm{M}+\mathrm{NO}_{2}+\mathrm{M}$ & $1.2 \times 10^{-31}$ & 1.8 & $3.0 \times 10^{-11}$ & 0 & 1 \\
\hline $\mathrm{O}+\mathrm{NO}_{2}+\mathrm{M}+\mathrm{NO}_{3}+\mathrm{N}$ & $9.0 \times 10^{-32}$ & 2.3 & $2.2 \times 10^{-11}$ & 0 & 1 \\
\hline $\mathrm{N}_{2} \mathrm{O}_{5}+\mathrm{N}+\mathrm{NO}_{2}+\mathrm{NO}_{3}+\mathrm{M}$ & $1.18 \times 10^{-3} \mathrm{e}^{-11180 / \mathrm{T}}$ & 2.8 & $7.52 \times 10^{14} \mathrm{e}^{-11180 / 1}$ & -0.8 & 3 \\
\hline
\end{tabular}




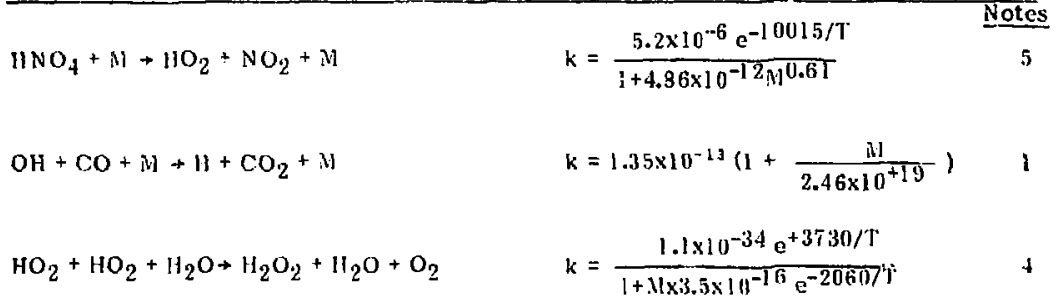

\section{notes TO ThBL, :}

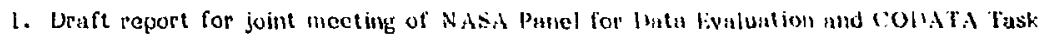
Group on Chemical linetics, I!gl.

2. Top expression is recommended in 1. He uppop one is used in thost of the 1.L.N. one-dimensional calculations hut bewuse uncertumty still larige, second expression is also often used.

3. Based on data in retercnee I and the equilibrtun (a)nstunt from NisS 513 (1978).

4. Based on Cox (1978).

5. Based on iraham et al. (1978). 
TABLE 3, Photolysis reactions. Alternative produets of reaction are showil in pareniheses, but they are not used in the 1981 chemistry.

\begin{tabular}{|c|c|c|}
\hline & Reaction & Note \\
\hline 1. & $0_{2}+20$ & 1,2 \\
\hline 2. & $\mathrm{O}_{3}+\mathrm{O}+\mathrm{O}_{2}$ & 1,3 \\
\hline 3. & $u_{3}+O\left({ }^{1} 0\right)+0_{2}$ & 1,3 \\
\hline 4. & $\mathrm{NO}_{2}+\mathrm{iOO}+\mathrm{OH}^{2}$ & 1,4 \\
\hline 5. & $\mathrm{~N}_{2} \mathrm{O}+\mathrm{N}_{2}+\mathrm{O}^{1}(1)$ & 4 \\
\hline fi. & $\mathrm{NO}+\mathrm{B}+\mathrm{O}$ & $\hat{5}$ \\
\hline$\pi$ & $\mathrm{HNO}_{3}+\mathrm{OH}+\mathrm{NO}_{2}$ & 4 \\
\hline я. & $\mathrm{H}_{2} \mathrm{O}_{2}+2 \mathrm{OH}$ & 4 \\
\hline 9. & $\left\|0_{2}+0\right\|+11$ & A \\
\hline 111. & $\mathrm{reONO})_{2}+\mathrm{r}_{2}+\mathrm{NO}_{3}\left(\mathrm{COO}_{2}+\mathrm{NO}_{2}\right)$ & 9,13 \\
\hline 11. & $11 \mathrm{CL} \rightarrow 1 \mathrm{H}+\mathrm{C} 2$ & 4 \\
\hline 12. & $(20+1 \cdot 2+1)$ & $\tau$ \\
\hline 13. & $\left.r 2 u+\left(-2+()^{2}\right)\right)$ & Not used \\
\hline 14. & $\mathrm{C}_{2} \mathrm{NO}_{2}+\mathrm{CQ}+\mathrm{NO}_{2}$ & 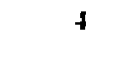 \\
\hline 15. & $u(20)+200+0$ & 7 \\
\hline 16. & $r_{2} C_{2}+2 r \cdot 2$ & 4,8 \\
\hline 17. & $\mathrm{FCl}_{3} \rightarrow 3 \mathrm{Cl}$ & 4,8 \\
\hline 18. & $\mathrm{ral}_{4}+4 c \mathrm{~s}$ &,+ 8 \\
\hline 19 & $\mathrm{~N}_{2} \mathrm{O}_{5}+\mathrm{NO}_{3}+\mathrm{NO}_{2}\left(2 \mathrm{NO} \mathrm{O}_{2}+0\right)$ & 4,6 \\
\hline 20. & $\mathrm{NO}_{3}+\mathrm{NO}+\mathrm{O}_{2}$ & 4 \\
\hline 21. & $\mathrm{NO}_{3}+\mathrm{NO}_{2}+\mathrm{O}$ & 4 \\
\hline 22. & $\mathrm{H}_{2} \mathrm{O}+\mathrm{H}+\mathrm{OH}$ & 9 \\
\hline 23. & $\mathrm{HNO}_{4}+1 \mathrm{HO}+\mathrm{NO}_{3}\left(11 \mathrm{O}_{2}+\mathrm{NO}_{2}\right)$ & 10,6 \\
\hline 24. & $110 \mathrm{Cl}+\mathrm{OH}+\mathrm{Cl}$ & 4 \\
\hline 25. & $\mathrm{PH}_{3} \mathrm{OH}: \cdot \mathrm{CH}_{3}+\mathrm{OH}$ & 4 \\
\hline 26 & $\mathrm{CH}_{2} \mathrm{O}+11 \mathrm{CO}+11$ & 11 \\
\hline 27 & $\mathrm{CH}_{2} \mathrm{O} \rightarrow \mathrm{CO}+\mathrm{H}_{2}$ & 11 \\
\hline 28 & $\mathrm{CH}_{3} \mathrm{Cl}+\mathrm{CH}_{3}+\mathrm{Cl}$ & 4 \\
\hline 29. & $110 N O+O H+\mathrm{NO}$ & 4 \\
\hline 30. & 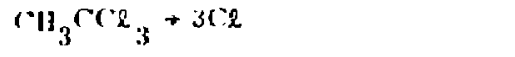 & 4,8 \\
\hline 31. & ( $F C-21+2 C 2$ & 4 \\
\hline 32. & $\mathrm{CFC}-13+\mathrm{Cl}$ & 13 \\
\hline 33. & $\mathrm{CFC}-112 \rightarrow 4 \mathrm{Cl}$ & 12 \\
\hline
\end{tabular}


Tiable 3. Continued

\begin{tabular}{|c|c|c|}
\hline & Reaction & Note \\
\hline 34. & $(\therefore 1)(-1+2 t)+C 2$ & 14 \\
\hline $3 \overline{5}$. & $C: F C-113+3 C: 2$ & 12 \\
\hline 36. & $\left(C^{\circ}-114+2 C^{\circ}\right.$ & 12 \\
\hline 37. & $(25(-1) 5+1) 2$ & 12 \\
\hline 38. & $\therefore \mathrm{C} C-22+C^{\prime} l$ & 4 \\
\hline
\end{tabular}




\section{NOTIS FUR TABLE 3.}

1. Contributes to the optical depth of the model at mosphere.

2. The Schumamn-liange hands are given a special trentment based on Hudson and llahle (1 972$)$.

3. The quantum yields of reactions a and 3 are given a special treatment based on the tenperature-dependent trentment of NASA Panel for linte Fvaluation (1981).

4. Haser on the dutu of NASA Panel for lata Evaluation (1 981). Where data for several temperatures are giver, we have used the datin at 2 2all $k$.

5. Nitrir oxide photolvsis is besed nn the trentment of l rederiek and Hudson (1979). We hate averaged rater over the sunil hemisphere fur daytime photnlysis.

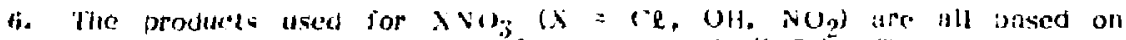

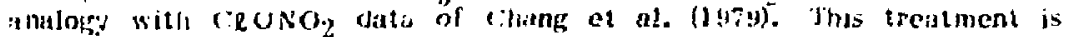
highlv ineerthin.

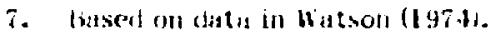

6. Promel chemistry has beon simbified.

9. Ireatment imscal on luompson el ni. (1963).

10. Treat ment hased on Molina and Molina (1980).

11. Treytuent based on cross seciions of iass et al. (1980). quantum yjeids based on lieriraff :nd (alvert (1976) and Vhortegt and liarneck (1979).

12. lased on recommentation of NASA Punel on Laborhtury lietsurements in N.IS: Reference Puhlimation 1 llt! (liucson and Reed, 1979 ).

13. Based on futsriel, et 41, , (1972).

14. Hased on Hlubrich and Stuhl (1980). 


\section{Radiative Processes}

Photodissocintion proeesses in the atmosphere are often citemely inportant mechanisins for the produstion and destruction of ehemienl species. In the ILL NL model, the rates of 38 photodissociation renetions (see lable 3 ) are updated as a function of altitude at each time step for all model calculations. It is necessary to continually updnte the photolissociation rates in order to properly account for chneses in photodissociation with changes in the distribution of important abscrbers of solar wavelengtus such as the species $\mathrm{O}_{3}, \mathrm{CO}_{2}$ and $\mathrm{NO}_{2}$ "

There is evidenee for a moderate temperature dependence in many photcabsorption aross-sections. Hith the exception of $\mathrm{O}_{3}, \mathrm{CH}_{2} \mathrm{O}$, NO and $\mathrm{O}_{2}$ bhotolysis. we have not trented this tmmerature dependence expljaitly, but have issed cross-scrions mensured at roughly $230^{\circ} \mathrm{K}$ for all temperatures. As a result veveral of our calcalated trace specics photodissociation rates should be more aceurate for the itrutosphere then the lower troposphere.

The solar flux is divided into 148 wavelength bins extending from $133.3 \mathrm{~nm}$ to 735.1 $\mathrm{nm}$. The size of the incividual bins inereases from $0.9 \mathrm{~nm}$ at lower wa velengths to $10.0 \mathrm{~nm}$ in the upper waveleng h region. The solar fluk at the top of the atllosphere is based on the recommendations of fiudson and lieed (1979). The solar yenitin angle is varier witia time for diurnal calculations and is held fixed for diurnal-rveraged enlouhtions at a value corresponding to noon at $30^{\circ} \mathrm{N}$ at solat equinisox.

In order to accurately compute photodissociation rates, it is important to describe radiative processes, such as inultiple scattering, in addition to attenuation by kases such $4 \mathrm{~S} \mathrm{O}_{2} \cdot \mathrm{O}_{3}$ and $\mathrm{NO}_{2}$. Hultiple scattering is included in the model using a simplified method that is computationally fast so that it can be used for diurnal calculations. The method is similar to that of Isaksen et al. (1977) in terms of the numerieal method but quite different in terms of the physical 
assumptions. The atmosphere is divided into optically thick layers and each laver can absorb and scatter radiation. The layer is assumed to seatter radiution isotropically with half of the scaltored flux going upward and the other half downward at an average zenith angle. The eartit's surface is also assumed to scat ter isotrcpically, and a surface albedo of 0.25 is used to approximate the effeet of clouds on the upward scattered radiation. Using a high surfuce albedo had no elouds gives results that are nearly identieal to those from dividing the atmosphere into clear and eloudy reginges and Hvernging the results (the exception being the region below the eloud layer, which is not important for the model applieations eonsidered here). For ench atmospheric layer there is a contribution to the solar flux density from the direct flux and by the diffuse fluxes incident on the layer from above and from below. The flux density due to the various fluxes together ean he tuuch greater (depending on the wavelength and nltitude) than the flux density eomputed cotsidering only gaseous absorption (1wher and Gelinas, 1976; Luther und Wuebbles, (976).

The effect of elouds on photolysis rutes in the lower troposphere is inclided by nuttiolying the photolysis rates ealculated in the model by a factor which is a funetion of altitude. The multipliers used are shown in Table 4. These multipliers are based on a subjective analysis of available data on the amount of cloudiness and eloud types in the troposphere (Hovt, 1976), cloud type altitude, cloud albedo, and eloud absorptivities. 
Table 4. Mutiplier of tropospheric ghotolysis rates to account for clouds

$\begin{array}{cc}\text { Altitude } & \text { Moltiplier } \\ 0 & 0.7 \\ 1 & 0.7 \\ 2 & 0.7 \\ 3 & 0.75 \\ 4 & 0.83 \\ 5 & 0.83 \\ 6 & 0.97 \\ 7 & 0.97 \\ 8 & 0.97 \\ 4 & 0.98 \\ 10 & 0.99 \\ 11 \text { on } & 1.0\end{array}$

\section{BUUNUAKY CONDITIONS}

The indel allows for either fixed concentrations or a flux condition at the surface as a lower boundary condition. lor most of the calculations, six species are assumed to have tixed concentrations (see Table 5), while a surface flux was assigned to the other speeies. Zero flux was assumed except for those species shown in Table 5 . Ihen those species with fixed boundary conditions in Table 5 are given Clux bounduries, a flux is determined to give an ambient concentration the same as those in Tabie 5.

Zero flux is assumed for all species except $\mathrm{NO}$ and $\mathrm{NO}_{2}$ at the upper boundary. NO and $\mathrm{NO}_{2}$ are assumed to have a very small hux from the mesosphere into the stratosphere. 
Water vapor concentrations are fixed in the troposphere and calculated in the stratosphere. Water vapor concentrations in the troposphere are based on $30^{\circ} \mathrm{N}$ datu from Oort and Rasmussen (! 0?!).

Inble 5. Houndary conditions

\begin{tabular}{|c|c|}
\hline \multicolumn{2}{|c|}{ Fixed llixing llatios } \\
\hline $\begin{array}{l}\mathrm{N}_{2} \mathrm{O} \\
\mathrm{CH}_{4} \\
\mathrm{H}_{2} \\
\mathrm{CH}_{3} \mathrm{Cl} \\
\mathrm{CO} \\
\mathrm{H}_{2} \mathrm{O}\end{array}$ & $\begin{array}{l}\text { 301. ppmv } \\
1.65 \text { ppmv } \\
0.56 \mathrm{ppmuv} \\
0.62 \mathrm{ppbv} \\
0.12 \mathrm{ppmv} \\
1.69 \times 11^{-2}\end{array}$ \\
\hline \multicolumn{2}{|c|}{ Surface 1:lux (moleciles en $\mathrm{en}^{-2} \mathrm{~s}^{-1}$ ) } \\
\hline $\begin{array}{l}\mathrm{NO} \\
\mathrm{NO}_{2} \\
\mathrm{HNO}_{3} \\
\mathrm{HCl}\end{array}$ & $\begin{array}{l}1.60 \times 10^{9} \\
3.30 \times 10^{9} \\
1.67 \times 10^{9} \\
3.67 \times 10^{10}\end{array}$ \\
\hline
\end{tabular}

\section{Sources and Sinks}

In addition to sources and sinks from the ehemistry and boundary eonditions deseribed above, there are additional sinks due to dry and/or wet removal for many species in the model. A source for nitric oxide from cosmic $r$ ry dissociation of $\mathrm{N}_{2}$ is also included bused on the results of Nieolet (1974).

Wet removal processes are parameterized by a first-order loss rate. The wet removal of the trace species $\mathrm{HNO}_{3}, \mathrm{H}_{2} \mathrm{O}_{2}, \mathrm{HCl}, \mathrm{ClO}, \mathrm{ClONO}$, CINu ${ }_{2} \mathrm{HNO}_{4}$, $\mathrm{HOCl}, \mathrm{CH}_{2} \mathrm{O}$ and $\mathrm{CH}_{3} \mathrm{OOH}$ is assumed to vary with 
altitude as shown in Table $6 . \mathrm{NO}_{2}$ is assumed to have a loss rate half the above rate.

Dry depositicn rates at the surface are also parameterized by a first-order loss rate as shown in Table 7 . These loss rates apply only when a species does not have a fixed sturface concentration.

Tathle t. Wet peinounl perameteriation

\begin{tabular}{|cc|}
\hline Altitude, $k$ Loss Rate, see & \\
\hline 0 & $3.86 \times 10^{-6}$ \\
1 & $3.86 \times 10^{-6}$ \\
2 & $3.86 \times 10^{-6}$ \\
3 & $3.86 \times 10^{-6}$ \\
4 & $3.86 \times 10^{-6}$ \\
5 & $3.86 \times 10^{-6}$ \\
$\dot{b}$ & $1.93 \times 10^{-6}$ \\
7 & $1.93 \times 10^{-7}$ \\
8 & $9.58 \times 10^{-7}$ \\
9 & $4.78 \times 10^{-7}$ \\
10 & 0 \\
\hline
\end{tabular}


Pable 7 . Dry deposition rates in the lowest layer $(z=0)$.

\begin{tabular}{|c|c|c|c|}
\hline Species & $\begin{array}{c}\text { Loss Rate } \\
\left(\sec ^{-1}\right)\end{array}$ & Species & $\begin{array}{c}\text { Loss Rate } \\
\text { (see }\end{array}$ \\
\hline$O\left(^{3} P\right)$ & $1.0 \times 10^{-5}$ & $\mathrm{NO}_{3}$ & $2.0 \times 10^{-5}$ \\
\hline$o_{3}$ & $4.1) \times 10^{-6}$ & $\mathrm{~N}_{2} \mathrm{O}_{5}$ & $2.0 \times 10^{-5}$ \\
\hline NO & $1.0 \times 10^{-6}$ & $\mathrm{H}_{2} \mathrm{O}$ & 0 \\
\hline $\mathrm{NO}_{2}$ & $3.0 \times 10^{-6}$ & $\mathrm{HNO}_{4}$ & $2.0 \times 10^{-5}$ \\
\hline $\mathrm{N}_{2} \mathrm{O}$ & o & frote & $2.0 \times 10^{-3}$ \\
\hline $\mathrm{HNO}_{3}$ & $2.10 \times 10^{-5}$ & $\mathrm{HCO}$ & $2.0 \times 10^{-5}$ \\
\hline Oll & $2.0 \times 10^{-5}$ & $\mathrm{CH}_{2} \mathrm{O}$ & $1.0 \times 10^{-5}$ \\
\hline $\mathrm{HO}_{2}$ & $2.0 \times 10^{-5}$ & $\mathrm{CH}_{3}^{2}$ & $2.0 \times 10^{-5}$ \\
\hline $\mathrm{H}_{2} \mathrm{O}_{2}$ & $2.0 \times\left[0^{-5}\right.$ & $\mathrm{CH}_{3} \mathrm{OOH}$ & $2.0 \times 10^{-5}$ \\
\hline $\mathrm{Cl}$ & $2.0 \times 10^{-5}$ & $\mathrm{CH}_{3} \mathrm{O}$ & $2.0 \times 10^{-5}$ \\
\hline $\mathrm{CIONO}_{2}$ & $2.0 \times 10^{-5}$ & $\mathrm{CH}_{3} \mathrm{O}_{2}$ & $200 \times 10^{-5}$ \\
\hline 010 & $2.0 \times 10^{-5}$ & $\mathrm{Co}$ & $5.0 \times 10^{-7}$ \\
\hline $\mathrm{CH}_{4}$ & 0 & $\mathrm{ClO}_{3}$ & $2.0 \times 10^{-5}$ \\
\hline$H_{2}$ & $1.0 \times 10^{-7}$ & oclo & $2.0 \times 10^{-5}$ \\
\hline $\mathrm{CH}_{2} \mathrm{O}$ & I & HUNO & $2.0 \times 10^{-5}$ \\
\hline $\mathrm{ClNO}$ & $2.0 \times 10^{-5}$ & & \\
\hline $110: 1$ & $2.0 \times 10^{-5}$ & & \\
\hline $\mathrm{CCl}_{4}$ & $\Delta$ & & \\
\hline
\end{tabular}

Other Physical Isata

The $\mathrm{N}_{2}$ and $\mathrm{O}_{2}$ distributions are fixed based on the U.S. Standard Atmosphere (197f). The temperature distribution, when held fixed, is usually based on the U.S. Standard At mosphere (1976) data for mid-latitudes. 


\section{TEMPERATURE FEEUBACK}

Although many calculations with the model are made assuming a constant temperature distribution with time, the capability also exists to determine the temperature explieitly at stratospheric altitudes as a function of time. When this temperature feedback process is included, the temperature profile above $13 \mathrm{~km}$ is calculated using a stratospheric radiative transfer model, and the temperature profile is specified at lower altitudes. The model includes solar absorption and long-wave interaction by $\mathrm{O}_{3}, \mathrm{H}_{2} \mathrm{O}$, and $\mathrm{CO}_{2}$, along with solar absorption by $\mathrm{NO}_{2}$. The techniques adopted for trenting long-wave radiative transfer are the same as those deseribed by Ramenalhan (1979). This formulation was chosen because it is computationally efficient, and its accuracy has been demonstrated (Ramanathan, 1974, 1976) by comparison with much more complex models. The effects of und justification for the simplifying assumptions used in the model are diseussed b; Ramanathan (1976).

$A$ band absorptance formulation is used to treat the $9.67 \mathrm{~m}$ band of $\mathrm{O}_{3}$ and the fundamental and several hot and isotopic bands of $\mathrm{CO}_{2}$ in the $157 \mathrm{~m}$ region. An emissivity formulation is used to treat long-wave radiative transfer by $\mathrm{H}_{2} \mathrm{O}$. Solar absorption by $\mathrm{O}_{3}$ is trented by using the empirical formulation given by Lindzen and will (1973). The band absorptance formulation by loughton (1963) is adopted for solar absorption by $\mathrm{H}_{2} \mathrm{O}$, and the band absorptance formulation by Rumanathan and Cess (1974) is adopted for solar absorption by $\mathrm{CO}_{2}$. The empirical formulation of Luther (1976) is used for solar absorption by $\mathrm{NO}_{2}$. Solar absorption by $\mathrm{O}_{3}$ and $\mathrm{NO}_{2}$ are treated independently because absorption by these species is wenk in the region where their absorption bands overlap. Solar radiation scattered from the troposphere is included by assuming an albedo of 0.3. Doppler broadening effects are included for $\mathrm{CO}_{2}$ and $\mathrm{O}_{3}$ as deseribed in Appendix B of Kamanathan (1976). The temperature dependences of the band absorptance and band intensity are included in the longwave calculations of $\mathrm{CO}_{2}$ and $\mathrm{O}_{3}$. 
A single eloud layer is included at $6.5 \mathrm{~km}$ with $42 \%$ eloud cover as was suggested by Cess (1974). The lapse rate within the troposphere is assumed to be $-6.5 \mathrm{~K} / \mathrm{km}$, and the temperature at the earth's surface is specified to be $288 \mathrm{~K}$.

\section{DIURNAL AND DIUR NAL-AVERAGED MODELING}

In addition to the capability for diumal ealetlations, we have also developed a fully diurnal-averaged model that is consistent with our diurnat model. The diurnal model is used to generate species profiles for comperison with measurements and for perturtation studies involving slbart lime integrations (e.g., solar eclipse effects). The diurnal-nveraged model is used for perturbation and sensitivity studies involving longer timc integrations. There is a significant computer time saving in using the diurnal-averaged model for calculations longer than a few model days.

The procedure that is used in developing the fully diurnat-averaged model is also applicable to two-dimensional models. If the continuity equation is averaged over a time period $(24$ hours in our casej that is very small compared to the time scale of the problem of interest, then one obtains averaged terms of the form $\overline{k_{i j}} \overline{c_{i} c_{j}}$ and $\overline{J_{i} c_{i}}$ where $c_{i}$ is the concentration of species $i$ at time $t$ and altitude $z, k_{i j}$ is the two-body chemical rate coefficient, and $J_{i}$ is the photodissociations rate coefficient for species $i$.

We define the diurnal weighting fiactors $\alpha_{i j}(z)$ and $\beta_{j}(z)$ by

$$
\overline{k_{i j} c_{i j}}=\alpha_{i j} \overline{k_{i j}} \overline{c_{i}} \overline{c_{j}}
$$

and

$$
\overline{J_{i} c_{i}}=B_{i} \vec{J}_{i} \vec{c}_{i}
$$


Since $k_{i j}$ is defined and is independent of time, we have

$$
\alpha_{i j}=\widetilde{c_{i} c_{j}} / \widetilde{c_{i} c_{j}}
$$

and

$$
B_{i}=\overrightarrow{J_{i}} c_{i}, \overrightarrow{J_{i}} \vec{c}_{i} \text {. }
$$

The computation of photodissociation rates ean be an expensive purt of stratospherie inodel calculntions, hence evaluation of $J_{i}$ 's in the diurnal-averaged model ean he expensive. If we define $\beta_{i}$ by

$$
B_{i}=\overline{s_{i} c_{i}} /\left(j_{i}^{\text {noon }} \overline{c_{i}}\right) \text {. }
$$

then the computation in the diurnit-averaged model is greatly simplifjed. Thie diurnal nodel is used to determine $\overline{c_{i} c_{j}}, \overline{j_{i} c_{i}}, \overline{c_{i}}, \overline{c_{j}}$ and $j_{i}^{\text {noon }}$ so that $\alpha_{i j}$ and $B_{j}$ can be obtained for every chemical and photochemical reaction in the madel.

A basic assumption in this approach is that $\alpha_{i j}$ and $\beta_{i}$ are relatively insensitive to changes in $c_{i}$ and $c_{j}$ This is generally the case, however, because the $\alpha_{i j}$ and $\beta_{i}$ primarily represent rumctional weighting factors which are sensitive to the functicial shape of the diturnal yariations in $c_{i}$ and $c_{j}$ and not to changes in the absolute magnitude of $c_{i}$ and $c_{j}$. So long as there is no drastic change to stratospheric ozone, there should be very little change in the diurnal functional shape of all the species. If there are signifieant changes, the diurnal model can be used to reevaluate the $\alpha_{i j}$ and $\beta_{j}$ and iterate this averaging process. 


\section{REFERENCES}

Bass, A. M., L. C. Glasgow, C. Miller, J. P. Jesson, and D. L. Filkin, "Temperature Dependent Absorption Cross Sections for Formaldehyde $\left(\mathrm{CH}_{2} \mathrm{O}\right)$. The Fffect of Formaldehyde on Stratospheric Chlorine Chemistry:" in Proceedings of the NATO Advaneed Institute on Atmospheric Ozone, Portugal, 1980, Available as U.S. Dept. of Transportation Report FAA-EE-80-20, 1980.

Cess, R. D., "Radiative Transfer Due to Atmospheric Water Vapor: Global Considerations of the Farth's Frevgy Balance," J. Quant. Spectrose. Rudiat. Ttansfer, 14, 861-871, 1974.

Ctrung, J. S., A. C. Ilindnarsh, and N. k. Madsen, "Simulation of Chemical kinetics Transport in the Stratospherc in Stiff nifferential Systems," edited by R. A. Willoughby, Plenum Publishing r'orp., New York, p. 51 ff, 1974.

Chang, J. S., "Simulations, Perturbations, and Interpretations," in Proceedings of the 3rd ClAP Conferelise, U.s. Jept. of Transportation, Cambridge, $\lambda$. Report DOT-'TSC-OST-74-15, 330-341, 1974.

Chang, J. S., J. R. Barker, J. E. Davenport, and U. H. Golden, "Chlorine Nitrate Photolysis by a New 'Technique: Very Low Pressure Photolysis," Chem. Phys. Lett., 60, 385-390, 1979

Cox, lì. A, "Kincties of $\mathrm{HO}_{2}$ Radieal Reactions of Atmospheric Interest," presented at the $\$ 1: 10$ symposium on the Geophysical Aspects and Consequences of Change in the Composition of the Stratosphere, Toronto, Jinne 26-30, 1978, tis No No. $511,1978$.

Davidson, J. A., I1. I. Sehilf, T. J. Brown, and C. J. Howard, "Temperature Dependence of the Rate Constants for Reactions of $\left.{ }^{1}{ }^{1} D\right)$ Atoms with a Number of Halocarbons," J. Chem. Phys., 69, 4277-4279, 1978.

DeCiraff, B. A., and J. G. Calvert, "A Study of the Primary Processes in $\mathrm{CH}_{2} \mathrm{O}$ and $\mathrm{CU}_{2} \mathrm{O}$ Photolysis, J. Amer. Chem. Soc., 89, 2247-2253, 1967.

Duewer, H. H., D. d. Wuebbles, H. K. Hllseesser, and J. S. Chang, "NO Catalytic Ozone Destruction: Sensitivity to Rate Coefficients," J. Ceophys. Res., 82, $935-942,1977$.

Frederick, J. E. and R. D. Hudson, "Predissociation of Nitric Oxide in the Mesosphere and Stratosphere," J. Atmos. Sci., 36, 737-745, 1979.

Graham, K. A., A. M. Iviner and J. N. Pitts, Jr., "Pressure and Temperature Dependence of the Unimolecular Decomposition of $\mathrm{NO}_{2} \mathrm{NO}_{2}, "$ J. Chem. Phys., 68, 4505-45I 0, 1978.

Hampson, R. F., "Chemical Kinetic and Photochemical Data Sheets for Atmospheric Reactions," U.S. Dept. of Transportation Report No. FAA-EE-80-1 7, 1980. 
Houghton, J.T., "The Absorption of Solar Infrared Radiation by the Lower Stratosphere," Quart. J. Roy. Neteorol. Soc., 89, 31 9-331, 1963.

Hoyt, D. V., "The Radiation and Energy Budget of the Earth Using Both Ground Based and Satellite-Derived Values of Total Cloud Cover," NOAA TR ERL $362-A$ R $4,1976$.

Hubrich, C., C. Zetzach and F. Stuhl, "Absorptionspektren von Halogenierten Methanen von 275 bis $160 \mathrm{~nm}$ bei Temperaturen von 298 und $208 \mathrm{k}$," Ber. lunenges: Phys. Chem, 81, p. 437-442, 1977.

Hubrich, C. and F. Stuhl, "l'le Ultraviolet Absorption of Some Halogenated Methanes and lithanes of Atmospheric Interest," J. Photochem., 12, 93-107, I 980.

H.Idson, R. D. and S. H. Mahlr, "Photndicenciation Rates of Wolecular Oxygen in the

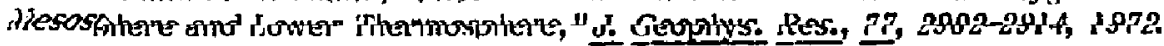

Hudson, R. D. and E. 1. Reed, "The Stratosphere: Present and Future," NASA Refere nce Publication $1049,1979$.

Isaksen, I. S. A., K. 1. Midtbo, J. Sunde, and P. J. Crutzen, "A Simplified Method to Include Molecular Miltiple Seattering and Reflection in Calculations of Photon Fluxes and Photodissociation Rates," Geophysica Norwegiea, 31, 1]-26, 1977.

Lindzen, R. s. and D. I. Will, "An Analytical Formula for Heating Due to Ozone Absorption," J. Atmos. Sei., 30, 513-515, 1973.

Luther, F. M., "A Parameterization of Solar Absorption by Nitrogen Dioxide," J. Appl. Meteorol., 15, 479-481, 1976.

Luther, F. N. and R. J. Gelinas, "Effect of Moleculer Multiple Seattering and Surface Albedo on Atmospheric Photodissociation Rates," d. Ueophys. Res., 81, 1125-1132, 1976.

Luther, F. M. and D. J. Wuebbles, "Photodissociation Rate Calculations," Report UCRC-789I I, Lawrence Livermore Laboratory, Ljvermore, CA, IY76.

Luther, F. M., J. S. Chang, W. H. Duewer, J. E. Penner, R. L. Tarp, and D. J. Wuebbles, "Potential Environmental Effects of Aircraft Emissions," Lawrence Livermore National Iaboratory Report UCRL-5286i, 1979.

Molina, L. 'T. and M. J. Molina, "Ultraviolet Absorption Cross Sections of $\mathrm{HO}_{2} \mathrm{NO}_{2}$ Vapor," presented at the 14 th informal Conference on Photochemistry, Newport Beach, CA, March 30-April 3, 1980, also U.S. Dept. of Transportation Report FAA-EE-80-7, 1980. 
Nhortgat, G. k., and P. Hitreek, "CU atho $\mathrm{ll}_{2}$ Quantum bields in the Photodecomposition of Formaldetryde in Air," d. Chem. Phus., in, 3639-365l, 1979 .

NASA Panel for Uata Evaluation, "Lhenical Kinetic and thotochemical liata for Use in Stratospheric Modeling," Jet Propulsion I Aboratory, Publication 79-25, 1974.

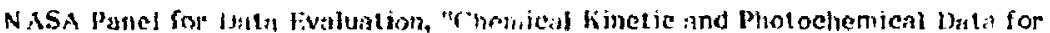
Use in Stralosploric Vorleline. Evaluntion Number t," Jet Tropulsion laborntory Publiciation ห)-3, I!S1.

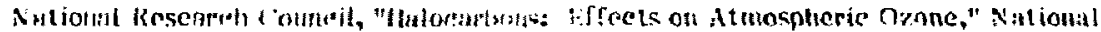

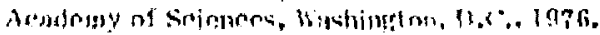

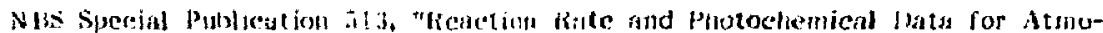
spheric ("hemistry -- 1977," N. I'. 114mpson, Jr. and 1). riarvin (eds.), ivational

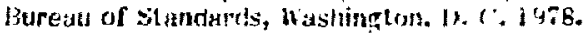

Nicolet, W., "On the Produetion of Nitrie Uxide ty Cusmie Rays in the Vesosphere

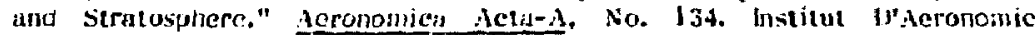
Spatiale de lielgique, Wrissels, 194 4.

Oort, A. H. and E., M, Rasinusen, "Atanspherie Cireulayion Statisties," NOAA Professional Paper a, 197i.

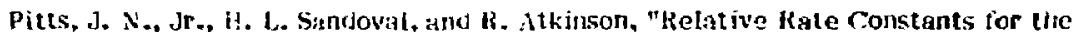
Reretion of $U\left({ }^{\prime}(l)\right.$ Atoms witi Fluorocurbons and $\mathrm{N}_{2} \mathrm{U}^{\prime \prime}$ Chem. Whys. lett., put p. 31-3t, 147t.

Ramanathan, V., "ג Simplified Stratospheric hadindise Transfer bodel: Theoreticat

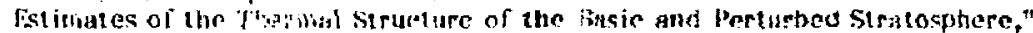
paper prosemted at the Second bifersiational Conferenec on the Environmental

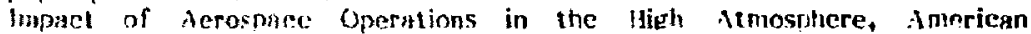
Wheteorological Socicty/smetiean inctitute of Aeronauties and istronauties, San biego, calit., Jily $8-16$, InTt.

Ramanatiwn, V.e "kadiatuve Transfer Within the Eartis Troposphere and Strntosplyere; A Simplified Kadintive-Conveetive bintel," 3. Mumos. Sei., 33, $1334-134 t, 1976$.

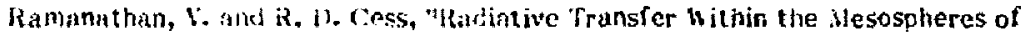
Venus and kars," 1stropius. J., 188, 14:-416, 1974.

Thompson, H. A., P. Harteck ark: R. R. Heeves, Ar., "Ultraviolet Ansorption roeifieients of $\mathrm{CO}_{2}+\mathrm{CO}, \mathrm{O} \% \mathrm{H}_{2} \mathrm{O}, \mathrm{N}_{2} \mathrm{O}, \mathrm{N}_{3}, \quad \mathrm{NO}, \mathrm{SO}_{2}$, and $\mathrm{CH}_{4}$ Between 1850 and"4001 A." I. Geophts. Fes. 68, 6731-643f, 1963. 
U.S. Standfard Atmosphere, 1976, NOAA-S/T 76-156 2, U.S. Governmert Printing uffice, $n$ ington, 1.,..1976.

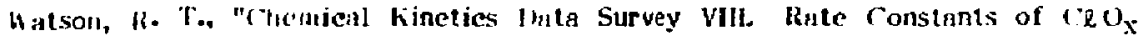
of Atmospheric unterest," NBSIR i4-516, National Rurean of Slandards, is astington, 1). (.., 1974.

D.ju:clm:10451I 


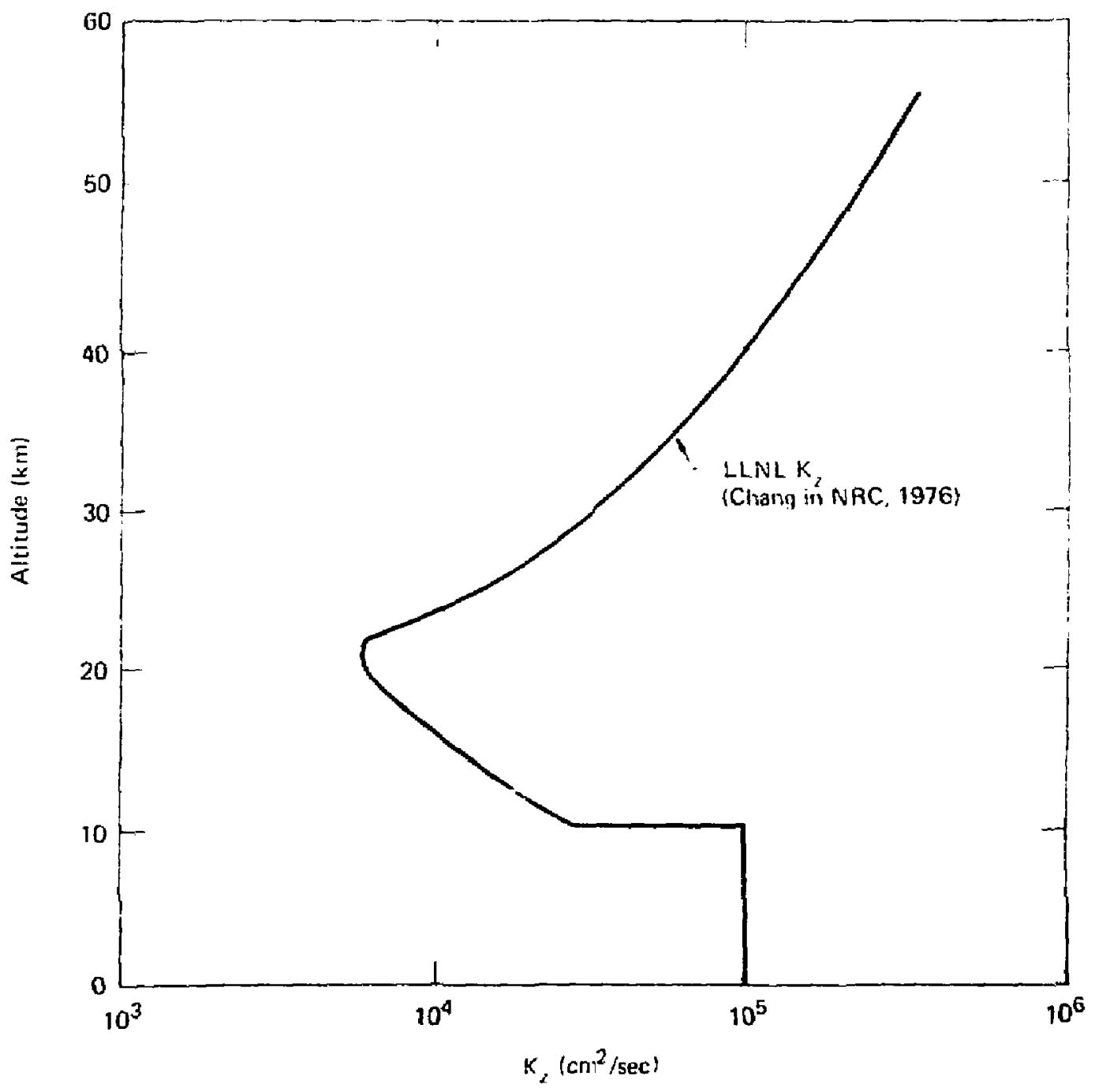

Finure 1. Diffusive transort coefficient primarily ured in LLIJ $1-$ in nojel. 